\title{
三点法に上る走向傾斜角の測定
}

西 村 嘉 四 郎*

\section{On the Three Points Method in Measurement of Strike and Dip}

\author{
by Kashiro Nishimura
}

\begin{abstract}
In this paper, the author discussed three points method in measurement of strike and dip on aerial photographs. As a result, it is emphasized that such measurement is highly depend on the balance between recognition of three points on same bedding plane and measurement procedure including calculation. And application of the streometer-type instrument with stereoscope will be enough for such measurement.
\end{abstract}

はじめに 地質構造を明らかにするためには，地層 の走向と傾斜角の数量的確認が必須な要件である。こ れらは写真上で写真測量の原理ならびに機器を応用し て測定できる。この測定は通常現地においてクリノ メーターあるいはプラントン・コンパスによって測定 され，時には地形図上に地質境界を正確にプロットし た上で，等高線とこれとの関係から算出される。

立体対写真上で同一地層面上にある著明な 3 点の位 置と高低差（比高）を求めて，これらの值から走向と 傾斜角を求める方法について検討を加えた結果，立体 鏡と視差測定桿だけによって机上で十分信頼できる值 が得られることが明らかになった。しかしここの方法 では若干の計算を伴なうが立体図化機を利用する場合 には計算過程をかなり省略することができ，かつ迅速 に高い精度の值が得られる。地層の走向执よび傾斜角 は種々の条件から考察して地層面が明らかに識別でき る場合には野外における测定あるいは，地形図を利用 して算出するよりはるかに高い精度であることは疑い ない。野外調查において鬼首地区では地質部松野久也 技官，上磯地区では元鉱床部非金属課河田茂麿技官の 御指導と御協力を得たここに謝意を表する。

\section{目的}

野外調查を前提として種々の情報や資料をもとに室 内に打いて空中写真の立体観察から地質図作成に必要 な要素が判定されることは広く知られているところで ある。立体観察において常に垂直距離が水平距離に 対して 3〜5 倍に誇張して観察され，このため僅かの 起伏量も極めて容易に観察できる利点もあり，これを

* 地質調査所
考慮に入れると，低角度の傾斜角はかなり高い精度で 推定できる（Ray 1960，64ページ）。しかし写真に 傾きがある場合には付近に対照物として信頼性の高い 基準面（湖水面，海面など）がない限り誤った推定が 行なわれ，甚しい場合には傾斜方向が逆となるような 錯覚さえ起り得る。反対に傾斜の大きな場合には推定 值の感覚誤差か真の傾斜角に大きく影響する。そこで 簪密な算定が心要になってくる。しかし，現在普通一 般に使われている空中写真では特定の場合を除いて， 地層の走向と傾斜角とについて困化機を用いないで， 図解と視差々の測定値から十分信頼できる值がえられ る。以下，その方法について検討する。

\section{各種測定法の利害得失}

走向および傾斜角の室内における測定方法として次 が考えられる。

1. 地形図 (等高線図) を利用して算出する方法

2. 立体図化機を利用する方法

3. 立体鏡と視差測定桿による方法

これら 3 つの方法の利害得失について比較検討すれ ば次のとおりである。

\section{地形図を利用して算出する方法}

写真上で判定し，あるいは現地で確認した地層境界 を地形図上に正確に移写した上で，測定されるもので ある。しかし，地形図を介して間接的な作業段階を経 るので，種々の誤差が伴なうし移写そのものについて 必問題がある。移写作業について考えてみると, 写真 と地図では投影が既に異なる。すなわち，写真はレン ズの中心投影であり，地図は平面投影（厳密には若干 異なる）とみてよい。写真の場合には地表の地物（透 明度のよい浅海は海底地形まで）悉く表現され実景に 
近い。しかし、レンズに近い物体程像が大きく军りま た位置は起伏による放射状偏位によって偏位し部分的 に縮尺は一定でない。これに対して地図は縮尺は一定 であるが表現に限度があって，目的によって作図の精 度は精粗様々である。実測 (地上測量)による場合の 大半は細部について，間接的測距測高作図であるから 施行技術者の主観が強く地形に反影し原形を忠実に表 現しえない。つまり傾斜地形の作図基準となる高さに ついて，等高線上が正しく同じ高さの部位を示して いるとは限らない。すなわち, 機械を置いて测定した 場所の精度は高いが, その周辺の起伏に対して無数に 近い点を測定するようなことは実際上不可能であっ て, 測定点と測定点の間は主観によって作図されるも のである。

また地物も記号化しているので, その関係位置（縮 尺に応じた）は必ずしも的確に表現しえない場合が多 い。写真測量によって正確に作られた地形図は別とし て写真上で判読, 識別されたデー夕を, いわゆる, 地 形図上に正確に移写することは極めて困難であるばか りでなく，確実性に乏しい。よって地形図を介して算 出されるこれらの值の信頼性は低いものである。

\section{立体図化機を利用する方法}

立体図化機を利用すれば高精度で，かつ迅速に作業 が進められ能率的で正しい結果がえられる。しかし， 立体図化機も用途に応じた各種のものがありその特徵 と性能を考え目的に適応したものを選ぶべきである。 これを大別すると次のとおりである。
高精度の要求には
あまり精度を必要とし
ないもの
C factar $1300 \sim 2000$

\section{精密図化機 高精度を要求するもの}

1.ここを利用する場合は図化機に関する知識に精 通し操作に熟達した技術者以外は利用できない。仮に 操作ができても機械固有の精度を望むことはできな w。

2. 機能に応じた精度の基準点が必要となり，その ために高精度の基準点測量をしなければならない。と きには他の目的のためにすでに設置された，基準点あ るいは公共测量その他で航空三角測量等の成果または これに代るべきものを利用することも考えられる。し かし，これら基準点は日本の現在の状態では限られた 地域に执いてしか利用することができない。ことに地 質調査に利用される多くは山間部でありその数は僅か なものである。新たに基準点を求めるとしても專門機 関に発註しても成果をえるまでには $2 \sim 3$ 月の日時を 要し、また自身でこの作業を行うとしても日時と労 力, および経費の伴なうことは当然である。ただしこ
の目的のみでなく地形図作成の作業と併せて同時に行 なう場合は有利である。

3. 精密図化機を新たに設置しようとするときは, 国産にはなく，すべて輸入に頼ることとなり，その上 現今では需用が多く生産国においても, これを満たし えず発注後 3 力年の歳月を要し, かつその機械を間断 なく常時使用しない機関にあっては, あまりに高価で 安易に購入されるものとは考兄れない。

4. この機械には透明ポジが使用され，判読資料を 直接記入することができない，また作業過程において 簡易困化機に比して能率的でないことも難色の一つで あろう。

\section{簡易図化機}

1. 専門的な技術者を必要としない。僅かの習練で 操作に熟達するので，簡単に目的が達成される。

2. 標定点も機械の精度に見合う程度のものでこと 足りるので, 5 万分の 1 あるいは 2.5 万分の 1 の地 図に示された三角点やその他，信頼できる基準点を写 真上に判定しても標定は可能である。また操作も簡単 なために能率的に測定ができる。

以上のことをよく考慮して使用する図化機は目的に 応じたものを選ぶべきである。いずれにしても走向お よび傾斜角の算定精度を最終的に左右する大きなもの は, 写真上での識別（この場合地層面の判定）と測定 と計算の三者の精度が均衡であることに注意する必要 がある。

例えば高性能の図化機を利用しても, 地層面の識別 判定が適切を欠くときは，いかに計算が綮密であって も最終目的に执いて確実性にそしいことは当然であ る。

\section{立体鏡亡視差測定桿による方法}

識別された同一地層面上の 3 点を眓解（射線法その 他）により関係位置を求め, 視差々 (比高) を決定し 算出するもので，図化機を利用するときょり若干計算 過程は多くなる。しかし, 調査基地でも, 研究室内の 片隅でも，場所を選ばず利用でき，専門的な技術もあ まり必要としない。しかも, 次に述べるような十分信 頼できる值がえられる。

\section{走向および傾斜角の算出}

観察から地層面の識別までの過程は省略して他の 2 点に重点をおく。

1. 判定された同一地層面の著明な点を選び朱墨で 明確に印をつける。射線法によってその水平位置を求 め座標を決定する。このとき地域内の方位を統一する 
ため既知方位から透導する。方位は真方位を用いるこ とが望しい。しかし，困難な場合は仮設点（線）を写 真上に決めて後日現地調査の際に測定して換算しても よい，比高は視差測定桿によって三点每に測定し全域 を統一する必要はない。

2. 測定値は算定の基礎となるものであるから反復 操作してその平均值を採用する。

基礎諸元から計算の過程を経て走向傾斜角を求める ものと，図解によって走向を決定し傾斜角を計算また は図表によって求める方法とがある（松野久也, 1963, 30 33 ページ)。同一地層面上で測定桿によって，等 視差点を求められるときは地層の走向は容易に決めら れる。いずれも地図の媒介なしに写真上から直接に值 を求められるので累積誤差を少くすることができる。 ただし罒解作業を併用するので，大きな縮尺の写真で あって，かつ傾きの少ないものを利用することに留意 すべきである。

鬼首地区の実例を参考をでに説明すると第 1 図，第 1 表のとおりである。

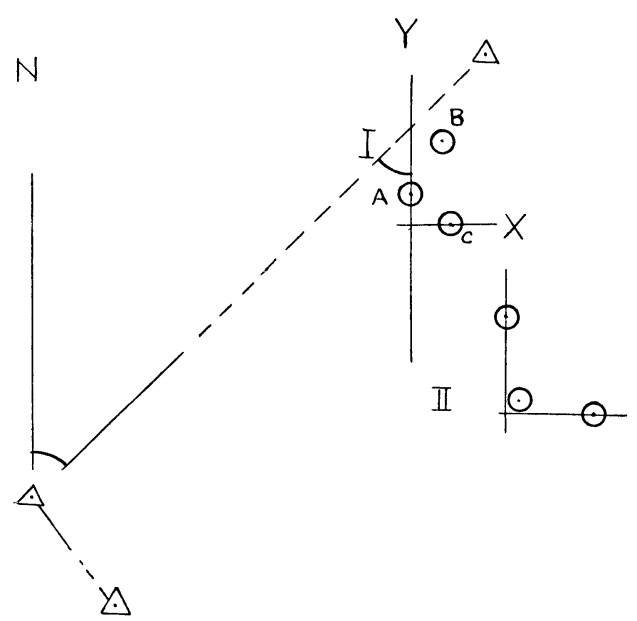

第 1 困 位置の測定

\section{計算の方法について}

走向と傾斜角の段階にわけて計算した（第 2 図参 照） $\mathrm{A} ， \mathrm{~B}, \mathrm{C}$ ，点は同一地層面に選んた 3 点である。 標高中位の $\mathrm{A}$ 点と水平面上に $\mathrm{D}$ 点（仮設）を算定し $\overline{\mathrm{AD}}$ は走向で $\mathrm{N}$ となす角が方位角となる。

$\mathrm{AD}$ 線上に $\mathrm{B}$ 点と直交する点を $\mathrm{E}$ 点とし， $\mathrm{B}$ 点から A点の面まで垂線を下しその交点を $\mathrm{B}^{\prime}$ 点とする。こ のとき $\overline{\mathrm{BE}}$ と $\overline{\mathrm{B}, \mathrm{B}^{\prime}}$ のなす角が地層の傾斜角である。 （附表に演算 I の実例を末尾に示す）

\section{計算値と実測值との比較}

計算值と現地においてクリノメーターによって測定
第 1 表 使用写真

M. $1066,7.8 .9 \mathrm{vv} 2$ 倍伸 $\mathrm{S} \div 20,000$

\begin{tabular}{|c|c|c|c|c|c|c|}
\hline \multicolumn{2}{|c|}{ 地点 } & 座＼cjkstart標 & \multirow{2}{*}{$\begin{array}{l}\text { 視 差 } \\
29.64\end{array}$} & \multirow{2}{*}{$\begin{array}{c}\text { 視差々 } \\
0.1\end{array}$} & \multirow{2}{*}{$\begin{array}{l}\text { 比 高 } \\
2 .\end{array}$} & \multirow{2}{*}{$\begin{array}{r}\text { 摘要 } \\
\mathrm{A}\end{array}$} \\
\hline & $1 \begin{array}{l}x \\
y\end{array}$ & $\begin{array}{c}226.72 \mathrm{~m} \\
97.35\end{array}$ & & & & \\
\hline I & $2 x_{y}^{x}$ & $\begin{array}{c}97.04 \\
0\end{array}$ & 31.42 & 1.88 & 39.1 & B \\
\hline & $3 \begin{array}{l}x \\
y\end{array}$ & $\begin{array}{c}0 \\
10,000\end{array}$ & 29.54 & 0 & 0 & $\mathrm{C}$ \\
\hline & $1_{y}^{x}$ & $\begin{array}{c}266.24 \\
0\end{array}$ & 29.52 & 0.22 & 0.04 & \\
\hline II & $\left.2\right|_{y} ^{x}$ & $\begin{array}{l}35.36 \\
41.60\end{array}$ & 32.18 & 2.68 & 56.00 & \\
\hline & 3 & $\begin{array}{c}0 \\
234.36\end{array}$ & 29.50 & 0 & 0 & \\
\hline
\end{tabular}

した值とを比較すると第 2 3 表のとおり。 上記の比較表について 2 者の值は一致していない。 しかし，平均すると近い値になる。その原因について 次のことが考えられる。

1. 観察時の地層面の判定識別の誤り

2. 困解による作業中の誤差

3. 計算過程の誤差

4. 実測值の誤り

4 者の中で地層面の判定識別は大きく影響するもの で，専門技術者の能力熟練の程度に左右される。また 写真の鮮明度, 撮影の季節, 表層被覆等種々の条件に 支配されるもので，写真地質学的立場から十分検討す べきのである。この地域の場合は写真地質学的に十 分検討して確信をもって判定し，かつ現地調査でも確 められたものである。位置抢よび比高測定にも反復測 定し平均值を採用した。使用した写真は米軍打よび日 林協撮影の二倍伸写真であり，優れたものとはいえな いまでも密着よりは有利である。視差測定桿による比 高測定では写真の傾きも大きく影響することが考えら れるが三点が僅かに $100 \mathrm{~m} \sim 500 \mathrm{~m}$ の範囲内に位置 しているのでその影響は無視できる程度のももであ る。さらに計算過程の誤りは検算によって除去でき る。以上の測定から地層面の算出におよぼす誤差は過 大なものとは考えられない。

写真上で選んだ 3 点の位置は現地において種々の条 件によって同一部位を実測できなかった。

現地での測定はクリノメーターによったが僅か 12 $\mathrm{cm} \times 6 \mathrm{~cm}$ の外形に磁針を内蔵した簡単なものであり, 測定そのものにも疑問が起きる。一見平坦にみえる地 層面も，局所的に必ずしも平坦ではない。 


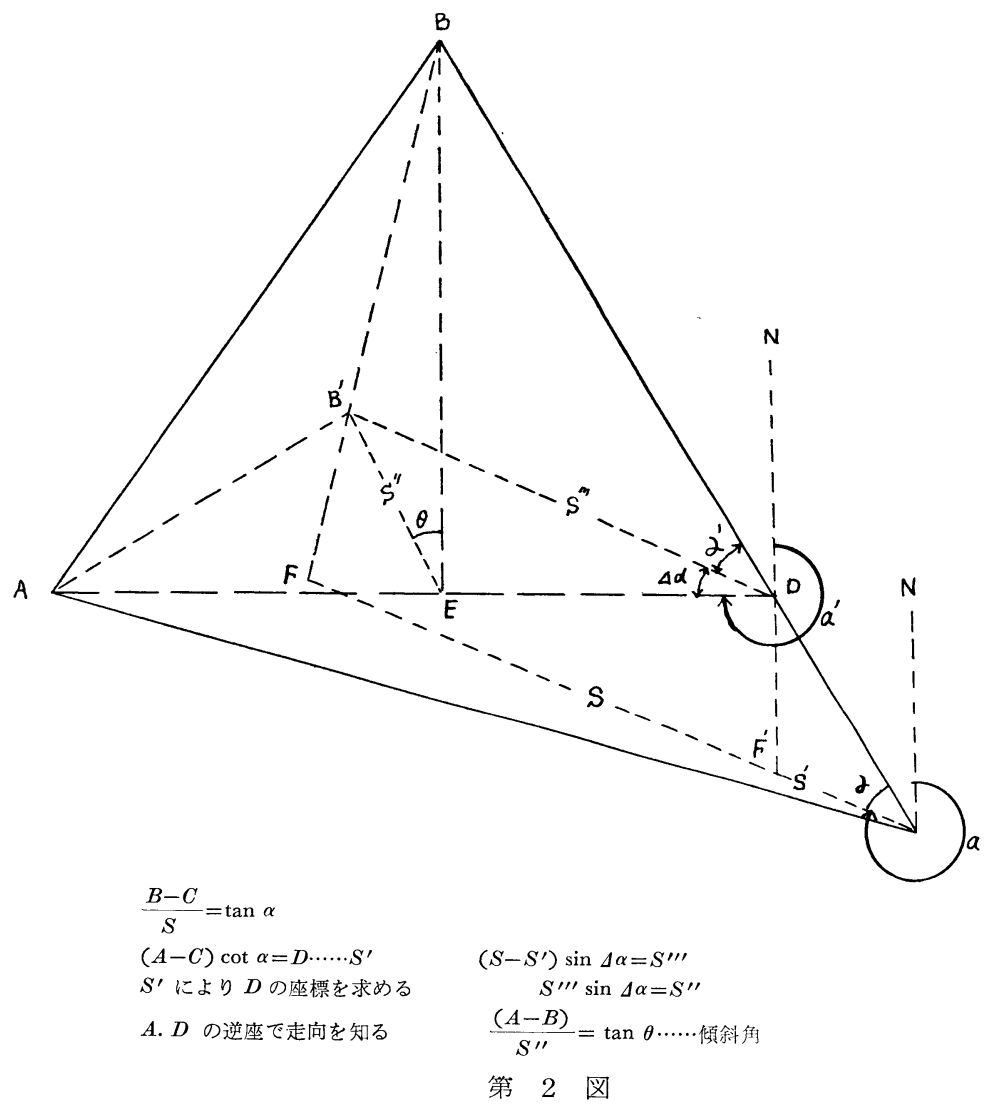

している。したがって極所 の僅かな面から测定した後 者よりは信頼性のあるもの. と考えられる。

むすび 露頭が非常によ くても地層面に著しい起伏 があっては走向傾斜の測定 はできない。すなわち， 露出している三点は平坦な 同一地層面上あると考える 場合に三点法は成立してい る。上記の方法は主として 写真を利用する面から検討 したのであるが，これに匹 敵する測定值は測地学的な 方法で地上測量を通じても 得られる。

しかし，後者はいかなる 機械を駆使しようとも現地 を跳査しなければ成果は得 られない。これに伴なう労 力と経費および必要とする 日時は大きいものである。 以上述べてきたような簡便 なお法でも比較的容易に走向打よび傾斜角の測定が可 能であり，さらにまた地上の測定では得られない精度

䙹定値と実測值との間に大きな値の相違がない限り 前者は地層面の僅かの起伏には関係のない平均值を現

鬼 首 地 区

\begin{tabular}{|c|c|c|c|c|c|c|}
\hline \multirow{2}{*}{ 地 点 } & 算 & 值 & \multirow{2}{*}{ 地 層 名 } & 実 & 值 & \multirow{2}{*}{ 備 } \\
\hline & 走 & 傾 & & 走 向 & 傾 斜 & \\
\hline I & $\mathrm{N} 0^{\circ} 40^{\prime \prime} \mathrm{E}$ & $26^{\circ} 31^{\prime} 53^{\prime \prime} \mathrm{E}$ & $\begin{array}{l}\text { 鬼首層凝灰岩質 } \\
\text { 砂岩。ひひ砅岩 }\end{array}$ & $\mathrm{N} 7^{\circ} \mathrm{W}$ & $27^{\circ} \mathrm{E}$ & $\begin{array}{l}\text { Iの測定地点付近 } \\
\text { を断層が東西に走 } \\
\text { ている }\end{array}$ \\
\hline II & $\mathrm{N} 42^{\circ} 25^{\prime} 48^{\prime \prime} \mathrm{W}$ & $24^{\circ} 7^{\prime} 20^{\prime} \mathrm{E}$ & " & $\begin{array}{lll}\mathrm{N} & 20^{\circ} & \mathrm{W} \\
\mathrm{N} & 40^{\circ} & \mathrm{W} \\
\mathrm{N} & 40^{\circ} & \mathrm{W}\end{array}$ & $\begin{array}{ll}40^{\circ} & \mathrm{E} \\
20^{\circ} & \mathrm{E} \\
20^{\circ} & \mathrm{E}\end{array}$ & \\
\hline
\end{tabular}

第 3 表 北海道道南上磯地区

\begin{tabular}{|c|c|c|c|c|c|c|}
\hline I & $\mathrm{N} 28^{\circ} 16^{\prime} \mathrm{W}$ & $21^{\circ} 32^{\prime} \mathrm{W}$ & $\begin{array}{l}\text { 八雲 } \\
\text { 板 状頁 } \\
\text { 粗 粒砂 }\end{array}$ & $\begin{array}{l}\text { 層 } \\
\text { 岩 } \\
\text { 岩 }\end{array}$ & $\begin{array}{lll}\mathrm{N} & 20^{\circ} & \mathrm{W} \\
\mathrm{N} & 20^{\circ} & \mathrm{W} \\
\mathrm{N} & 50^{\circ} & \mathrm{W} \\
\mathrm{N} & 40^{\circ} & \mathrm{W} \\
\end{array}$ & $\begin{array}{ll}15^{\circ} & W \\
15^{\circ} & W \\
30^{\circ} & E\end{array}$ \\
\hline II & $\mathrm{N} \quad 3^{\circ} 50^{\prime} \mathrm{E}$ & $34^{\circ} 23^{\prime} \mathrm{E}$ & "I & & $\begin{array}{lll}\mathrm{N} & 18^{\circ} & \mathrm{E} \\
\mathrm{N} & 10^{\circ} & \mathrm{E}\end{array}$ & $\begin{array}{ll}40^{\circ} & \mathrm{E} \\
20^{\circ} & \mathrm{E}\end{array}$ \\
\hline III & $\mathrm{N} 16^{\circ} 33^{\prime} \mathrm{W}$ & $36^{\circ} 50^{\prime} \mathrm{W}$ & "I & & $\begin{array}{lrl}\mathrm{N} & 8^{\circ} & \mathrm{W} \\
\mathrm{N} & 21^{\circ} & \mathrm{W}\end{array}$ & $\begin{array}{ll}40^{\circ} & W \\
30^{\circ} & W\end{array}$ \\
\hline IV & $\mathrm{N} 32^{\circ} 46^{\prime} \mathrm{E}$ & $32^{\circ} 22^{\prime} \mathrm{E}$ & $\begin{array}{l}\text { 黒松 内 } \\
\text { 砂 岩 泥 }\end{array}$ & $\begin{array}{l}\text { 層 } \\
\text { 岩 }\end{array}$ & $\mathrm{N} 40^{\circ} 35^{\prime} \mathrm{E}$ & $35^{\circ} \mathrm{E}$ \\
\hline V & $\mathrm{N} 32^{\circ} 9^{\prime} \mathrm{W}$ & $26^{\circ} \mathrm{E}$ & $\begin{array}{l}\text { 黒 松 内 } \\
\text { 泥 }\end{array}$ & $\begin{array}{l}\text { 層 } \\
\text { 岩 }\end{array}$ & $\begin{array}{l}\text { 軟質泥岩で } \\
\text { 崩壊のため }\end{array}$ & 分多く, \\
\hline
\end{tabular}


と作業が能率的あるで。また調査終了後においても疑 義あるときは，写真と反射立体鏡および視差測定桿さ えあれば，再検討は室内に招いて容易にできる利点を もっている。さらに高精能立体図化機まで行かなくと も簡易立体図化機の使用は精度および作業の能率上見 逃せない。しかし，1 モデル上で多くの測定を行なう 場合には有効であるが，僅かに 1〜2 の測定しか行な
うことができないような場合, 却って手数ばかりかか って甚だ非能率的である。

\section{交献}

1) Ray R.G. (1960) Aerial photagraphs in Geologic Interpretation and mapping Geol. Surv. Prof. Paper. No. 373. 230 p.

2）松野久也 (1963) 空中写真地質講座（12）地質 ニュース No. 108, pp. 30 33.
付表

演 算 I の 実 例 $\log \Delta y=2.01703$

$\log \Delta x=1.89785$

$\log \tan \theta \quad 0.11918$

$52^{\circ} 45^{\prime} 53^{\prime \prime}$

$3 \sim 2$ 方位角 $a 307^{\circ} 45^{\prime} 53^{\prime \prime}$

$$
\begin{aligned}
& \log \Delta x=1.89785 \quad \log \left(z_{3}-z_{2}\right)=1.59218
\end{aligned}
$$

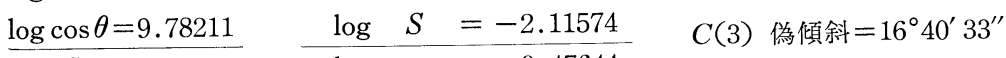

$$
\begin{aligned}
& \log S=2.11574 \\
& 130 \div 45
\end{aligned}
$$

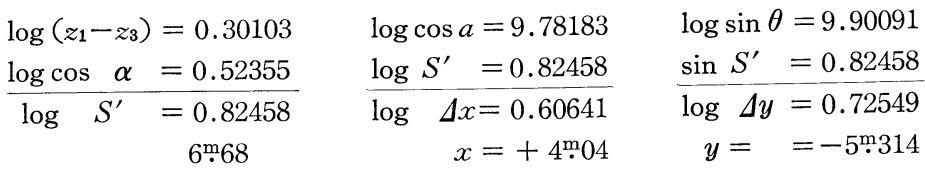

$$
\begin{aligned}
& D(4) \text { 座標 } x=4 \div 04 \quad y=98 \div 686 \\
& \begin{array}{ll}
x_{1}=226^{\mathrm{m}} \cdot 72 & y_{1}=97^{\mathrm{m}} \cdot 35 \\
x_{4}=4.04 & y_{4}=98.69 \\
\hline \Delta x=222.66 & \Delta y=1.34
\end{array} \\
& \log \Delta y=0.12710 \\
& \theta=0^{\circ} 20^{\prime} 40^{\prime \prime} \\
& \log \Delta x=2.34763 \\
& \overline{\log \tan \theta=7.779 .47}
\end{aligned}
$$

\begin{tabular}{|c|c|c|c|}
\hline ページ & 行 & 正 & 誝 \\
\hline 表 紙 & 8 & 能率比 $\Delta H / \sqrt{A}$ & 能率化 $\Delta H \sqrt{A}$ \\
\hline 目 次 & 7 & $\prime \prime$ & \\
\hline 13 & 枠内 1 列 8 & 23 日から 30 日まで & 23 日から日まで \\
\hline & 枠内 2 列 9 & 差は $30 \mathrm{~cm}$ であった。 & 差はであった。 \\
\hline & 枠内 3 列 $8-10$ & 毎朝毎夕…あふふふれ， & 毎朝毎夕道路は車と人であふれ，毎期毎夕・. \\
\hline 23 & 第 3 困 & 逆 & \\
\hline & 第 4 図 & 逆 & \\
\hline
\end{tabular}

$\mathrm{N} 0^{\circ} 20^{\prime} 40^{\prime \prime} \mathrm{E} 26^{\circ} 31^{\prime} 53^{\prime \prime} \mathrm{E}$

注 1. 演算は計算機のない場合を考えて対数を使用した 真数を用いても勿論よいので手馿れたものを利用すべきである。

2、四解で走向を決定し偭斜你測定に四表を用いる場合は藤田和夫著，地質戝の書き方と読み方 $174 \mathrm{p}$ 見かけの傾斜（共点図表） 利用すると便利である。

\section{正誤 表 （3 巻 4 号） 中 村 貢 治}

